\title{
8 Examining Gender (In)Equality in German Engineering
}

\author{
Considering the Importance of Interest, \\ Perceptions, and Choice
}

\author{
Jennifer Dusdal and Frank Fernandez
}

After the United States and China, Germany is the world's main producer of research in science, technology, engineering, and mathematics (STEM) fields. This development has been fostered by the institutionalization of strong research universities and extra-university research institutes (Dusdal et al., 2020). In addition, laboratories and research institutes within companies have established strong university-industry relationships (e.g. Dusdal, 2018; Dusdal, Powell, \& Oberg, 2019). Germany spends more per capita on STEM research and development than either the United Kingdom or France, which are two other major European leaders in STEM. Still, the persistent underrepresentation of women in STEM (Nimmesgern, 2016) has a massive negative impact on the labor force and economic growth. The European Institute for Gender Equality (n.d.) projected that achieving gender parity in STEM education would increase employment in the European Union (EU) by up to 1.2 million jobs. Additionally, the Institute projected that improving gender equality would increase the EU's per capita GDP up to $0.9 \%$ by 2030 and up to $3 \%$ by 2050 (or by up to $€ 180$ billion by 2030 and up to $€ 820$ billion by 2050).

The United Nations Educational, Scientific and Cultural Organization (UNESCO) has called for leaders around the world to address the persistent, near universal underrepresentation of women in engineering (UNESCO, 2015). Within the EU, countries face a noticeable labor force shortage in STEM. The European Commission (EG) forecasts 7 million job openings for the STEM sector by 2025. Thus, the EC and EU have implemented several measures to increase women's participation in STEM (e.g. UNESCO's For Women in Science Programme, funded by L'Oréal ${ }^{1}$ to address gender segregation in research and science, career challenges for women, a lack of women in leadership positions in academia and industry, gender imbalance in access to research funding, and gender-biased research (Fatourou et al. 2019).

As a global leader in STEM research, the German government has focused on improving women's attainment in engineering fields through the implementation of various national initiatives to foster equal opportunity and to attract and retain women in STEM fields (Best et al., 2013). Although Germany is at the forefront of producing talented graduates in STEM, in 2015 fewer than one out of three students were STEM graduates (OECD, 2017 as cited in Isphording \& Qendrai, 
2019). In a 2019 report, the Federal Ministry for Family Affairs, Senior Citizens, Women and Youth (BMFSFJ) declared that "in the face of digital transformation, demographic change and the resulting lack of skilled workers, it is important to attract young women to STEM careers and increase the number of women students, especially in computer science and electrical engineering" (BMFSFJ, 2019, p. 30).

Gender remains one of the most crucial factors in study choice and decision for engineering and natural sciences in Germany (Heine et al., 2006). Since the 1990s, English-language studies that examined German women's access to higher education often focused on enrollment patterns following the reunification of East and West Germany (e.g., Ammermüller \& Weber, 2005; Blossfeld et al., 2015). Scholars found that women in what used to be East and West Germany experienced different opportunities and challenges. For example, women earned a larger percentage of engineering degrees in East Germany than in West Germany; that is, there was a larger participation gap in STEM education between women and men in West Germany. However, the gender gap in what was West Germany began to improve as women experienced more opportunity and better pay in the engineering labor market. Even though women in East Germany historically had greater access and attainment to engineering education, they were still underpaid relative to men (Ammermüller \& Weber, 2005).

Beyond focusing on the German experience with reunification, there are several studies that address women's access to higher education or labor market outcomes (e.g., Becker, 2014; Blossfeld et al., 2015; Grave \& Goerlitz, 2012; Kim \& Kim, 2003; Meyer \& Strauß, 2019; Reimer \& Steinmetz, 2009; Wahrenburg \& Weldi, 2007). However, relatively few papers examine women as undergraduates (e.g., Ammermüller \& Weber, 2005; Schlenker, 2009). While some studies consider the extent to which women are underrepresented, scholars often overlook why women choose not to study STEM and how those reasons compare to men. Research has shown (e.g., Seymour \& Hunter, 2019, Best et al., 2013 for an overview) that several different reasons, including a maledominated STEM culture (Solga \& Pfahl, 2009a, 2009b) and subject specific environments, for example particular learning cultures or a competition-oriented atmosphere, increase the drop-out rates among women (Brainard \& Carlin, 2001; Derboven \& Winker, 2010; Hetze, 2011; Ihsen et al., 2009; Seymour \& Hewitt, 1997; Wolffram et al., 2009) and disable their promotion to top academic positions (GWK, 2019). Teenage women have significantly less frequent contacts with STEM in their leisure time and through internships than teenage men, which might impact their study decisions (Best et al., 2013). Other factors that influence study choice include interest in the subject and previous attainment in related subjects (Elster, 2014).

To enhance women's participation in STEM fields in academia it is important to increase early interest in STEM subjects. Starting at an early age, parents should encourage young girls to take interest in STEM (Elster, 2014). Similarly, teachers and other women role models at school should 
support STEM aspirations (Bottia et al., 2015; Dasgupta \& Stout, 2014). Teachers should work to reduce gender stereotypes that are associated with STEM school subjects - such as the idea that boys are better at math than girls (Carlana, 2019; Makarova et al., 2019). To make high academic positions attractive for women, it is essential to create more attractive and flexible research-oriented careers (Wissenschaftsrat, 2013).

Therefore, the purpose of this chapter is to consider why German women may self-select out of STEM fields and to identify potential opportunities to encourage more women to study STEM. In the next section of the chapter, we briefly describe Germany's education system, because "[s]chools can inspire, reinforce, or discourage students' interest in pursuing a STEM field of study in higher education" (Jacob et al., 2020, p. 62). Then we discuss broad patterns in women's access to STEM education and employment opportunities in Germany. After our review of prior literature, we present data to show different ways that gender matters in German STEM higher education. In closing, we introduce policies and initiatives that are meant to support women in STEM in Germany and consider ways that they might hold transferrable lessons for other countries.

\section{From Primary Education to Higher Education in Germany}

The German educational system contrasts with those of many other countries around the world. It features early allocation and strong school segregation: from the age of ten in most German federal states (Bundesländer), pupils are placed within a highly stratified secondary school system. These tracks lead to different postsecondary opportunities, some more academic and others more vocational. The system of German schooling and skill formation leads to relatively low (but growing) proportions of each cohort to enter higher education as full-time university students. Vocational training opportunities in Germany's "dual system" of school-based training and in-firm apprenticeships remain attractive. A relatively small percentage of each cohort graduating secondary schooling begins hybrid postsecondary vocational education and training (VET) and higher education programs, often referred to as "dual studies," that combine in-firm training with postsecondary academic studies (Graf \& Powell, 2017; Graf, 2013). Taken together, these features cultivate the idea of "German exceptionalism" in schooling, VET, and higher education (Powell \& Solga, 2011, p. 49).

Studies show that an increase in distinct pathways (vocational vs. academic) led to a larger gender gap in STEM occupational aspirations (Sikora \& Pokropek, 2012; Han, 2016). Although science and math are compulsory subjects for all students in Germany, it does not reduce the gender gap in STEM fields in higher education enrollments (Jacob et al., 2020). In the subsections that follow, we describe some of the characteristics of the German education system and how it creates distinct pathways for women's postsecondary opportunities. 


\section{From Primary to Secondary School}

During the 20th century, cohorts of German children increasingly attended schooling for longer stretches of their youth (Becker, 2003). German expansion of primary and secondary schooling during the 20th century was part of a global pattern (Baker, 2014), but the ways that Germany broadened participation in primary and secondary schools - ultimately leading to higher education - occurred within the unique context of Germany's existing highly stratified and segregated education system. After completing primary school at approximately 10 years of age, German youth may attend lower secondary school (Hauptschule), intermediate secondary school (Realschule), or upper secondary school (Gymnasium) (Kim \& Kim, 2003). A recent development in German schooling is the regionally-variant implementation of comprehensive schools (Gesamtschule), which combine Hauptschule, Realschule, and Gymnasium tracks (for an overview of education as a lifelong process in Germany see Blossfeld \& Roßbach, 2019).

Students are selected into one of the three secondary schools, which offer different curriculums of varying lengths. Lower secondary schools are universally accessible to students who complete primary schooling; they are less academically oriented and satisfy compulsory education requirements. The intermediate secondary schools offer a more academically oriented six-year course of study, which culminates in a certificate of completion. Finally, the upper secondary school track enrolls students for nine years, teaches a curriculum that prepares students to complete the Abitur (a qualification granted by passing standardized exams that is required to attend a research university, regardless of subject choice), and provides a direct pathway to enroll at a university (Kim \& Kim, 2003). Usually, all students who attend Gymnasium follow a similar curriculum until grade 10 or 11, with no specialization. Only in the last two or three years of schooling do students have some opportunities for specialization; at that point, students may choose different domains (in addition to core subjects). For example, advanced level students in the Gymnasium may select courses with intensified instruction in fields such as social sciences, STEM subjects, or foreign languages (Jacob et al., 2020).

Over the latter half of the 20th century, decreasing percentages of students attended the lower secondary schools, while the intermediate and upper secondary schools became increasingly well-attended (Becker, 2003). Becker (2003) argues that the decades of expansion of German schooling and the re-balancing of the secondary schools benefited German girls, in particular. The Abitur provides evidence that young women have long been prepared to succeed in postsecondary education. Beginning with cohorts who were born around the late 1970s, women have had a higher likelihood than men of attaining the Abitur (Becker, 2014).

\section{Access to Postsecondary Opportunities in Germany}

In Germany, access to higher education is more stratified than in other countries, such as the United Kingdom (Kim \& Kim, 2003). As previously 
described, the most direct route to a traditional research university is to attend upper secondary school (Gymnasium) and pass the Abitur. Students could instead pass the Fachhochschulreife to gain admittance to the universities of applied sciences. Alternately, one non-traditional way to access universities is to receive accreditation for competencies that students have gained through VET, though these alternative pathways are followed by very few (Freitag, 2012).

As with secondary schools, the two postsecondary tracks offer different options to students. The German case is unique from other chapters in this volume (e.g., the U.S. case) because its higher education system consists of a binary structure with two main types of universities: universities of applied sciences (Fachhochschulen or Hochschulen) that are more technically oriented and mainly focus on teaching as well as applied research, and traditional research universities (Universitäten), which provide undergraduate, graduate, and doctoral training and combine basic research with advanced teaching. Compared to the thousands of colleges and universities in the United States, the German higher education system is relatively small, with 126 research universities, 232 universities of applied sciences, and 51 art and music colleges (Powell \& Dusdal, 2017). Whereas Germany's system of secondary schooling is gradually becoming less stratified, scholars argue that inequality is not declining - and may be increasing - when it comes to attaining access to research universities (Blossfeld et al., 2015).

Whichever pathway German postsecondary students take, their studies are closely linked to their occupational outcomes. For example, research universities have historically been perceived as enhancing a student's "probability of entering the privileged and lucrative service class" (Kim \& Kim, 2003, p. 20). For this reason, "children from higher educational origin opt against the less prestigious universities of applied science and prefer the more prestigious research universities to preserve their advantages at the labour market" (Blossfeld et al., 2015, p. 157). The research universities offer greater opportunities for prestigious employment, but their graduates are also subject to spells of unemployment, unlike alumni of universities of applied sciences (Reimer \& Steinmetz, 2009).

Women increasingly enroll in both types of universities as a result of evolving gender norms, expanding access to higher education, and women attained greater earning potential in the labor market (Becker, 2014; Blossfeld et al., 2015). In winter term 2019-2020, 1.8 million students were enrolled at research universities, whereas 1 million were enrolled at universities of applied sciences. The proportion of women who attended universities $(51.7 \%)$ was a bit higher than at universities of applied sciences (45\%) (DESTATIS, 2020a). Although women's opportunities are relatively better, compared to women of earlier generations, they are still not equal to those of men. In the winter term 2019-20, about 1 million students at German universities and universities of applied sciences were enrolled in science and engineering, from which only $31.4 \%$ were women. The percentage of women students $(24 \%)$ was especially low in engineering (DESTATIS, 2020b). 
Analyses of those data from the German Centre for Higher Education Research and Science Studies (DZHW) on university dropouts show that women who study subjects where they make up less than $35 \%$ of enrollments "face a drop-out risk which is 1.5 times higher than men's and almost twice the women's" in a subject where they are better represented (Meyer \& Strauß, 2019, p. 451). Even though women fare well during admissions because they tend to have performed better in secondary school and to have more conscientious personalities than men (Isphording \& Qendrai, 2019), they may not be equitably retained within STEM fields. Comparing subjects within STEM more broadly, gender differences are highest in traditional STEM subjects (e.g., physics, chemistry, biology, engineering, math, and technology). Yet, the gender gap decreases, when STEM is defined as including medicine or health related disciplines. When focusing on engineering and technology, the gender gap more than doubles compared to a traditional classification of STEM disciplines (Jacob et al., 2020).

Meyer and Strauß (2019) suggest that women tend to be at larger risk of dropping out of higher education when they study university subjects that are dominated by men because women give themselves lower self-assessments of their academic performance. ${ }^{2}$ Additionally, Meyer and Strauß (2019) attributed women's higher risk of dropping out to their perceptions that their academic subjects were difficult. Conversely, the researchers identify several experiences that are related to reduced drop-out risk among German university students; these include positively interacting with peers and developing relationships with professors (Meyer \& Strauß, 2019).

\section{Why Study STEM? (Under)Employment Opportunities in Germany}

One common assumption is that students should be motivated to study STEM subjects because they offer access to lucrative employment. Labor markets in different countries provide various opportunity structures that might support or inhibit young women and men to strive for a career in STEM (Charles \& Bradley, 2009). Hägglung and Leuze (2020) point out that a post-industrial structuring of the labor market "increases the male-favorable gender expectation gap in STEM fields" (p. 16), but they acknowledge that it is empirically very difficult to separate whether the labor market has an impact on the gender gap in STEM expectations through socialization or rational decisions.

As in most countries, STEM graduates tend to be paid more highly than nonSTEM graduates. In the mid 2000s, the baseline starting salary for German engineering graduates was approximately $40 \%$ higher than for graduates in the arts and humanities (Grave \& Goerlitz, 2012). Controlling for a variety of variables individual and employer-related variables, reduced but did not eliminate the pay gap across fields. Engineers who were men continued to be paid more than women engineers (Wahrenburg \& Weldi, 2007). Moreover, women are promoted less frequently, win fewer research grants when they stay in academia 
(Nimmesgern, 2016), establish fewer international collaborations (Zippel, 2017), and show less international collaboration patterns than men (Kwiek \& Roszka, 2020; Larivière et al., 2013), which is a crucial driver for academic career development and scientific productivity (Wagner, 2018).

There are two competing explanations for why women earn less than men in engineering - both are problematic. Several scholars argue that pay disparities are the result of the gender composition of particular professions (e.g., Ammermüller \& Weber, 2005; Reimer \& Steinmetz, 2009; Wahrenburg \& Weldi, 2007). In other words, the first interpretation is that women are paid less in occupations in which they do not make up a critical mass of the workforce and are paid more in occupations in which they make up a majority of workers. For instance, Ammermüller and Weber (2005) note that in the former East Germany, women had better access to engineering education than in former West Germany, yet women typically earn more as teachers than as engineers; the authors note that this pattern implies "that it is not worthwhile for either men or women to choose a field of study which is dominated by the opposite gender" (Ammermüller \& Weber, 2005, p. 12).

Another group of studies suggests that women engineers earn less than men because they tend to work part-time. Kim and Kim (2003) examine data from the German microcensus (Mikrozensus) and Labour Force Survey data from the United Kingdom. They find that the pay gap between German women and men is smaller than the pay gap between British women and men when analyses are limited to full-time employees in a broad range of occupations. Relative to British women, "German women seem to be more willing to choose part-time jobs, even if they are highly educated" (Kim \& Kim, 2003, p. 24).

A separate study of census data estimates that only $65 \%$ of engineers who were women worked full-time (compared to $93 \%$ of men), $23 \%$ worked part-time (compared to $3 \%$ of men), and $13 \%$ were not in the labor force (compared to $4 \%$ ). The percentage of engineers who work full-time drops from $65 \%$ to $42 \%$ among mothers. Although 23\% of women engineers work part-time, $40 \%$ of mothers who are engineers work part-time. Comparatively, 95\% of engineers who are fathers work full-time (Schlenker, 2009). Because the engineering labor market is so gendered, Germany has an untapped "reserve of female engineers ... [an] estimated 24,400 women who graduated in engineering are not in the labour force, [and an] additional 40,500 female engineers work part-time" (Schlenker, 2009, p. 260). Yet, Schlenker (2009) notes that too few women earn degrees in engineering, so even if more women worked full-time, Germany would still need to educate more women in engineering.

There is a large body of literature that discusses highly diverse reasons why women are leaving STEM (for an overview see Blickenstaff, 2005) and that acknowledges that women and men differ in their choice of field of study (for an overview see Jacob et al., 2020). First, studies indicate that women prefer to enroll in humanities or education, whereas men are more likely to enroll in engineering or science (e.g., Barone, 2011; Charles \& Bradley, 2002; Smyth \& Steinmetz, 2008; Xie et al., 2015). Additionally, subjects at secondary school 
seem to have an impact on study decisions in postsecondary education (Chachashvili-Bolotin et al., 2016; Mann \& DiPrete, 2013; Riegle-Crumb et al., 2012). For example, Jacob and colleagues (2020) find that studying more STEM subjects at secondary school is a predictor of studying STEM in higher education; yet they note that prior schooling in STEM is a necessary, but not sufficient, condition to enter related fields within higher education.

Third, labor market structures, economic decisions, and expected labor market returns explain varying study decisions (Moorhouse, 2017; Fervers et al., 2020 as cited in Jacob et al., 2020). Especially in STEM, a decrease of drop-out rates would be a very effective answer to fill the gap of academicallyqualified personnel and to increase the labor supply (Heublein, 2014). On the other hand, very recent research suggests that smaller representation of women in STEM fields is not necessarily a disadvantage if gender-neutral occupations also provide high wages (Hägglung \& Leuze, 2020; Magnusson, 2013). Fourth, career aspirations have an impact on STEM enrollments (e.g., Tai et al., 2006; Xie \& Shauman, 2003). Compared to other countries, Germany is characterized by a very "leaky pipeline" in STEM fields (Leemann et al., 2010 , p. 299) that results in a massive loss of women in STEM throughout their educational and occupational careers (Solga \& Pfahl, 2009a). This can generally be described as "layers in a sex-based filter" (Blickenstaff, 2005, p. 384) and a multi-complex problem with different issues.

Except for a few studies (e.g., Solga \& Pfahl, 2009a, 2009b; Isphording \& Qendrai, 2019; Jacob et al., 2020), there is limited English-language literature on women who study STEM fields in German higher education. The literature highlights characteristics of the German educational system that influence student pathways to higher education (i.e., secondary school track, Abitur, attending a traditional university or a university of applied sciences) or dropping out of higher education (e.g., Isphording \& Qendrai, 2019). Additionally, key studies focus on women's disparate outcomes in the labor market. However, there are too few studies that examine women's motivations and concerns about studying STEM subjects at universities. Finally, among the studies we discuss in this literature review, most rely on older data that provide important context but may no longer apply to more recent cohorts of students - such as focusing on differences between East and West Germany prior to unification. In the next section, we provide data to identify challenges and opportunities for women in STEM at German universities.

\section{Findings from the 2008 Panel of School Leavers}

The German Centre for Higher Education Research and Science Studies (DZHW), with funding from the German Federal Ministry of Education and Research, regularly conducts panel surveys of secondary school leavers (i.e., high school graduates). The survey collects three waves of data from participants who have the requisite qualifications to attend a German research university or a university of applied sciences. The 2008 cohort was the 17th 
cohort to receive the cohort-panel-design survey. The first wave of data was collected between 2007 and 2008, and the second wave of data was collected between 2008 and 2009. The final wave of data was collected between 2012 and 2013 (Heine et al., 2017).

We analyzed data from the second wave of the 2008 panel study of school leavers to determine the extent to which German women consider studying STEM, even if they do not choose to do so. We then seek to examine why women may choose or opt-out of studying STEM fields. Because many prior studies on German women in STEM focus specifically on engineering, we too examine engineering sciences as a subset of STEM subjects. We analyzed unweighted data and examined gender differences for two survey items. The first item asked: "Have you considered starting a course in the engineering sciences at a university or university of applied sciences?" Respondents who stated that they had definitely chosen to not study engineering were directed to a follow-up question: "Why did you decide not to start an engineering sciences degree?" The first question offered mutually exclusive responses; the second question allowed respondents to select multiple answers.

First, we seek to identify whether there are many women who consider studying engineering but then pursue a different subject. We also compare whether larger percentages of women consider and then forego studying engineering compared to men. We find that there was a larger percentage of women $(80 \%)$ than men $(20 \%)$ who simply did not consider studying engineering at all. Among respondents who considered engineering, but stated that it "played no part in their final decision," 60\% were women. There was a near even split among those who "seriously considered" studying engineering but declined to choose that subject. Among respondents who were still undecided and continued to show interest in engineering, the majority $(71 \%)$ were men. In the final category - those who definitively chose engineering - seven in ten were men and only three in ten were women. See Figure 8.1.

Other than lack of interest, women and men both gave four common reasons for choosing not to study engineering. Although the reasons were similar, the percentages differed between women and men. The most popular reason women gave for not studying engineering was that prior learning about technology discouraged them from studying engineering; approximately three in ten women selected that reason, where fewer than two in ten men chose the same response. The second most common response among women was that they were unable to complete prerequisite courses. Although more than one in four women identified prerequisites as a barrier (26\%), a slightly higher percentage of men selected the same response (28\%). Another 16\% of women stated that "an engineering degree would be too boring" (compared to $15 \%$ of men who said the same). The fourth most common answer was that engineering was "quite attractive, but I'd possibly not be able to handle the degree" (14\% of women, $22 \%$ of men). Only about $4 \%$ of women stated they were interested in studying engineering, "but as a woman, I don't think my chances are very high." See Table 8.1. 


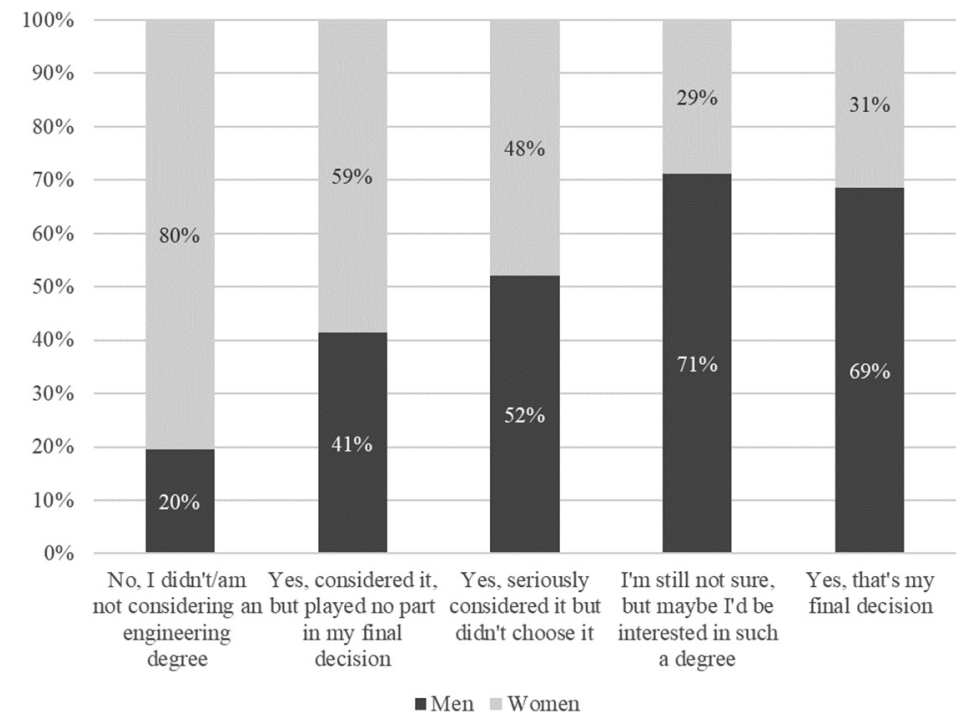

Figure 8.1 Percentages of secondary school leavers who considered studying engineering at a university or university of applied sciences.

Note: Authors' analysis of the 2nd wave of the DZHW Panel Study of School Leavers 2008. Translation of original survey items provided by DZHW.

Table 8.1 Reasons High School Leavers Decided Not to Start an Engineering Degree

\begin{tabular}{|c|c|c|c|c|}
\hline & Womer & & Men & \\
\hline & Yes & No & Yes & No \\
\hline My interests lie in other fields & $86 \%$ & $14 \%$ & $79 \%$ & $21 \%$ \\
\hline $\begin{array}{l}\text { The way technology was taught at school had a } \\
\text { negative effect on me }\end{array}$ & $30 \%$ & $70 \%$ & $17 \%$ & $83 \%$ \\
\hline $\begin{array}{l}\text { I cannot fulfill the prerequisites because of my } \\
\text { subject specializations in school }\end{array}$ & $26 \%$ & $74 \%$ & $28 \%$ & $72 \%$ \\
\hline I think an engineering degree would be too boring & $16 \%$ & $84 \%$ & $15 \%$ & $85 \%$ \\
\hline $\begin{array}{l}\text { Find the engineering profession quite attractive, but } \\
\text { I'd possibly not be able to handle the degree }\end{array}$ & $14 \%$ & $86 \%$ & $22 \%$ & $78 \%$ \\
\hline $\begin{array}{l}\text { The courses in the technical fields which interest me } \\
\text { are too far removed from real life }\end{array}$ & $4 \%$ & $96 \%$ & $5 \%$ & $95 \%$ \\
\hline $\begin{array}{l}\text { I'm interested in a degree/career in engineering but } \\
\text { as a woman I don't think my chances are very high }\end{array}$ & $4 \%$ & $96 \%$ & - & - \\
\hline $\begin{array}{l}\text { An engineering degree would be too work-intensive } \\
\text { for me }\end{array}$ & $3 \%$ & $97 \%$ & $5 \%$ & $95 \%$ \\
\hline $\begin{array}{l}\text { Because the career prospects are too insecure for me in } \\
\text { the subject area I'm interested in }\end{array}$ & $2 \%$ & $98 \%$ & $5 \%$ & $95 \%$ \\
\hline
\end{tabular}

Note: Authors' analysis of the 2nd wave of the DZHW Panel Study of School Leavers 2008. Translation of original survey items provided by DZHW. 
In addition to looking at the structure of educational systems and national enrollment data, we should consider how individual women make choices about whether to study STEM. Figure 8.1 shows that interest in STEM is not a binary construct. Although some women never considered majoring in engineering, other women gave varying degrees of consideration to studying engineering. In fact, some women who delayed choosing a final subject stated that they might still be interested in engineering. It seems that interest and time may both play factors in whether women ultimately pursue engineering.

Based on our findings, we argue that researchers should consider individual interests, perceptions, and choices when examining national gender disparities in STEM. For example, prior literature suggested that women may be less interested in studying engineering because women engineers often work parttime and earn less than men in engineering (e.g., Schlenker, 2009). Yet, less than $2 \%$ of women were concerned that "the career prospects are too insecure for me" in engineering. On the other hand, research shows that female students in engineering have an advantage compared to women in other disciplines to achieve an academic career (Barlösius \& Fisser, 2017). Women who decide to study engineering or even strive for an academic career seem to have a distinct aspiration for success, based on three attributes: a high level of self-confidence, a strong interest in STEM, and great determination to pursue their interests (Fisser, 2019). Women can and do succeed in STEM; thus, future research must continue to focus on choice and self-selection out of STEM. We now turn to considering ways that scholars, governments, and universities, can work toward improving gender equity in STEM.

\section{Implications for Research, Policy, and Practice}

The purpose of this chapter was to provide insights into the extent to which women consider studying engineering and select another field. Then, we wanted to understand their justifications for that choice. The 2008 Panel of School Leavers offered an opportunity to examine women in engineering as a subset of STEM. Although focusing on engineering is a limitation, it also allowed us to be consistent with prior literature on women in STEM in Germany. We found that examining data on subject choice offers several implications for supporting women's attainment in STEM fields.

First, we showed that German policymakers and educators may work to increase the percentage of women who consider studying STEM when they leave secondary school to attend a traditional research university or a university of applied sciences. Additionally, there was nearly a 20\% gap between women and men who considered engineering but then disregarded it when making a final decision. Recruitment, advising, or mentoring programs should target potentially persuadable women (i.e., those who show some interest in studying engineering) and encourage them to continue to see that as a viable and attractive option for university studies. Future research may expand on that choice process to reveal why some women first consider but then finally 
disregard engineering as a potential field of study. Additionally, approximately $30 \%$ of undecided respondents who could have still chosen to study engineering were women. Scholars and policymakers should work together to consider whether additional information, incentives, or sources of social and academic support could convince undecided women to ultimately choose engineering or some other STEM field.

When we examined the reasons women gave for not studying engineering, we found ways that organizations could incorporate changes to support women (interested) in STEM. For instance, prior negative exposure to technology or technology-related curriculum seemed to inhibit women's interest in engineering. Educators should try to incorporate different, culturally relevant pedagogical practices to engage students through learning with and without technology (e.g., Scott et al., 2009). Additionally, one-quarter of women stated that they were unable to complete the prerequisite courses they needed to be engineering majors. Schools should find ways to reduce prerequisite courses or move to co-requisite models: co-requisite courses take what instructors assume needs to be learned sequentially and instead allow students to simultaneously learn skills and concepts in the same academic term (see, e.g., Bullock et al., 2017). Finally, German schools and universities can adopt social cognitive perspectives to help women see themselves as able to complete STEM degrees, which are associated with increased interest in the subject (Kelly, 2016). Having outlined a short summary of our results, and implications for research, policy, and practice, we conclude with a presentation of initiatives that should encourage more women in Germany to study STEM, and to decrease persistent gender disparities.

\section{Promising Policies and Practices}

Though more can certainly be done, Germany has taken important steps toward improving gender equality in STEM. We briefly share some of those efforts, encouraging educators to consider integrating lessons detailed here into existing initiatives to attract women to STEM and to retain talented women in STEM higher education.

Since 2001, Germany's Federal Ministry for Family Affairs, Senior Citizens, Women and Youth (BMFSFJ) and the Federal Ministry of Education and Research (BMBF) have supported a national Girls' Day to encourage girls to consider STEM and technical fields where they are underrepresented (Best et al., 2013). ${ }^{3}$ In 2019, almost 100,000 young women and more than 10,000 organizations participated in the 19 th edition. ${ }^{4}$ The annual Girls' Day tradition is supported by funding from multiple federal agencies. The national campaign is recognized throughout the country with thousands of local events that engage nearly 2 million girls. Assessment data show that most girls are satisfied with Girls' Day programing. More importantly, seven in ten girls learn about professions that catch their interest, and many girls are able to see themselves pursuing technical or STEM professions (Girls' Day, n.d.). 
Similarly, in 2008 Germany's Federal Ministry of Education and Research launched the "Go MINT" - National Pact for Women in MINT careers" initiative (MINT is sometimes used interchangeably with the STEM acronym in German; directly translated MINT = mathematics, informatics, natural sciences, and technology). The purpose of Go MINT is "to open up the innovation potential of women for STEM in the long term, to attract more women to STEM careers and to present a modern image of STEM professions" (Komm Mach MINT, n.d.). Like Girls' Day, a national network of stakeholders organize local activities to encourage women to study STEM. The Go MINT initiative claims success for nearly doubling the number of women who choose STEM subjects as they enter higher education (Komm Mach MINT, n.d.).

Apart from such national efforts, individual universities have undertaken significant efforts to support women in academia and particularly in STEM. For example, the University of Augsburg created UniMento, a university mentoring program that pairs women faculty with women students (University of Augsburg, n.d.). Through UniMento, women students in STEM can receive career counseling and networking opportunities. The program seeks to establish year-long mentoring relationships and offers workshops to both mentors and mentees about how to have an effective mentoring relationship.

These three initiatives illustrate existing opportunities to address women's perceptions and choices about STEM fields - engineering in particular. For example, a sizable percentage of women said they did not choose to study engineering because they thought "an engineering degree would be too boring." If those women received mentoring through a program like UniMento, they might find satisfying career options. Additionally, initiatives like Girls' Day and Go MINT may help increase the percentage of women who consider and choose STEM fields. The variety of implemented initiatives gives the impression that gender equality in STEM has improved over the last decade, but evaluations indicate that attempts to attract enough women to STEM have failed to reach intended goals (GWK, 2019). Greater efforts must be made to expand women's success in STEM - and thus bolster Germany's achievement of its potential in these fields.

\section{Conclusion}

Prior studies examined inequality in STEM as a result of structural factors (e.g., differences in schooling between East and West Germany, educational tracking, qualifications like the Abitur, unequal employment, and earnings). However, it remains difficult to disentangle the actual reasons for sustained gender differences in STEM empirically (Isphording \& Qendrai, 2019). In future research, scholars will need to use multiple data sources and methods, including sequential analyses of progression or trajectories (Haas \& Hadjar, 2019) to investigate why women are underrepresented in STEM. Higher education research in Germany faces three problems that need to be tackled for a more in-depth explanation for 
student drop-out: definition and measurement of drop-out; clarification of the individual, institutional, and social causes; and dangers of above-average dropout of specific risk groups (here, women in STEM) (Heublein, 2014). For a better understanding of gender disparities in occupational preferences, it would be necessary to use longitudinal data to investigate changes in such preferences as well as to disentangle cultural and structural aspects that might have an impact on individual outcomes on the labor market (Hägglung \& Leuze, 2020, p. 17). By analyzing federal data on school leavers, we suggest that it is necessary to consider individual perceptions, motivations, and choices about academic subjects.

Germany leads Europe and is one of a few global leaders in STEM. Around the globe, nations use their higher education systems to promote economic growth and compete in STEM science production (Fernandez \& Baker, 2016, Fernandez \& Powell, in press). This chapter demonstrates that Germany has an opportunity to maintain and expand its considerable scientific STEM excellence by pursuing greater gender equality in STEM higher education.

\section{Notes}

1 https://en.unesco.org/science-sustainable-future/women-in-science

2 Meyer \& Strauß (2019, p. 448) found that self-assessed academic performance was statistically related to dropping out even after controlling for perceived difficulty of the subject and students' final grades.

3 In 2011, the equivalent "Boy's Day" has been implemented by the two ministries to attract more boys to underrepresented professions like education, social affairs, or health care. For more information, see https://www.boys-day.de

4 https://www.girls-day.de

\section{References}

Ammermüller, A., \& Weber, A. M. (2005). Educational attainment and returns to education in Germany: An analysis by subject of degree, gender, and region (ZEW Discussion Paper No. 05-017). Centre for European Economic Research. ftp://ftp.zew.de/pub/zewdocs/dp/dp0517.pdf.

Baker, D. P. (2014). The schooled society: The educational transformation of global culture. Stanford University Press.

Barlösius, E., \&. Fisser, G. (2017). Wie deuten Wissenschaftlerinnen im Maschinenbau ihren Erfolg [How do female academics in mechanical engineering interpret their success]? Forum: Qualitative Sozialforschung, 18(1).

Barone, C. (2011). Some things never change: Gender segregation in higher education across eight nations and three decades. Sociology of Education, 84(2), 157-176.

Becker, R. (2003). Educational expansion and persistent inequalities of education: Utilizing subjective expected utility theory to explain increasing participation rates in upper secondary school in the Federal Republic of Germany. European Sociological Review, 19(1), 1-24.

Becker, R. (2014). Reversal of gender differences in educational attainment: An historical analysis of the West German case. Educational Research, 56(2), 184-201. 
Best, K. L., Sanwald, U., Ihsen, S., \& Ittel, A. (2013). Gender and STEM in Germany: Policies enhancing women's participation in academia. International Fournal of Gender, Science and Technology, 5(3), 292-304.

Blickenstaff, J. C. (2005). Women and science careers: Leaky pipeline or gender filter? Gender and Education, 17(4), 369-386.

Blossfeld, P. N., Blossfeld, G. J., \& Blossfeld, H.-P. (2015). Educational expansion and inequalities in educational opportunity: Long-term changes for East and West Germany. European Sociological Review, 31(2), 144-160.

Blossfeld, H.-P., \& Roßbach, H. G. (Eds.). (2019). Education as a lifelong process: The German National Educational Panel Study (NEPS) (2nd ed.). Springer Verlag.

Bottia, M. C., Stearns, E., Mickelson, R. A., Moller, S., \& Valentino, L. (2015). Growing the roots of STEM majors: Female math and science high school faculty and the participation of students in STEM . Economics of Education Review, 45(C), 14-27.

Brainard, S. G., \& Carlin, L. (2001). A six-year longitudinal study of undergraduate women in engineering and science. In M. Lederman, \&. I. Bartsch (Eds.). The gender and science reader (pp. 24-37). Routledge.

Bullock, D., Callahan, J., \& Cullers, J. B. S. (2017). Calculus reform: Increasing STEM retention and post-requisite course success while closing the retention gap for women and underrepresented minority students (Paper No. 18474). Proceedings ASEE Annual Conference E Expo. https:// scholarworks.boisestate.edu/cgi/viewcontent.cgi?article $=1$ 196\&context $=$ math_facpubs

Carlana, M. (2019). Implicit stereotypes: Evidence from teachers' gender bias. The Quarterly Fournal of Economics, 134(3), 1163-1224.

Chachashvili-Bolotin, S., Milner-Bolotin, M., \& Lissitsa, S. (2016). Examination of factors predicting secondary students' interest in tertiary STEM education. International Journal of Science Education, 38(3), 366-390.

Charles, M., \& Bradley, K. (2002). Equal but separate? A cross-national study of sex segregation in higher education. American Sociological Review, 67(4), 573-599.

Charles, M., \& Bradley, K. (2009). Indulging our gendered selves? Sex segregation by field of study in 44 countries. American Fournal of Sociology, 114(4), 924-976.

Dasgupta, N., \& Stout, J. G. (2014). Girls and women in science, technology, engineering, and mathematics: STEMing the tide and broadening participation in STEM careers. Policy Insights from the Behavioral and Brain Sciences, 1(1), 21-29.

Derboven, W., \& Winker, G. (2010). Tausend Formeln und dahinter keine Welt. Eine geschlechtersensitive Studie zum Studienabbruch in den Ingenieurwissenschaften [A thousand formulas and yet no world behind. A gender sensitive study on drop-out in engineering]. Beiträge zur Hochschulforschung, 32(1), 56-78.

Dusdal, J. (2018). Welche Organisationsformen produzieren Wissenschaft. Zum Verhältnis von Hochschule und Wissenschaft in Deutschland [Which organizational forms produce science? The relationship of higher education and science in Germany]. Campus Verlag.

Dusdal, J., Oberg, A., \& Powell, J. J. W. (2019). Das Verhältnis zwischen Hochschule und Wissenschaft in Deutschland: Expansion - Produktion-Kooperation [The relationship between higher education and science in Germany: Expansion-Production - Collaboration]. In N. Burzan (Ed.), Komplexe Dynamiken globaler und lokaler Entwicklungen: Der Verhandlungsband des 39. Kongresses der Deutschen Gesellschaft für Soziologie vom 24.-28. September 2018 an der Georg-August-Universität Göttingen [Complex dynamics of global and local developments: Conference proceedings of the 39th Congress of the German Sociological Association from September 24-28 at the Georgia Augusta University of Göttingen]. 
Dusdal, J., Powell, J. J. W., Baker, D. P., Fu, Y. C., Shamekhi, Y., \& Stock, M. (2020). University vs. research institute? The dual pillars of German science production, 1950-2010. Minerva, 58, 319-342.

Elster, D. (2014). First-year students' priorities and choices in STEM studies-IRIS findings from Germany and Austria. Science Education International, 25(1), 52-59.

Fatourou, P., Papageorgiou, Y., \& Petousi, V. (2019). Women are needed in STEM: European policies and incentives. Communications of the ACM, 62(4), 52-57.

Federal Ministry for Family Affairs, Senior Citizens, Women and Youth (BMFSFJ). (2019). Report of the Federal Republic of Germany. https://www.unece.org/fileadmin/ DAM/Gender/Beijing_20/Germany.pdf

Fernandez, F., \& Baker, D. P. (2016). Educational transformations: Work and government policy in the schooled society. In J. Cote \& A. Furlong (Eds.), Handbook of the sociology of higher education (pp. 369-379). Routledge.

Fernandez, F., \& Powell, J. J. W. (in press). Neo-institutional approaches to understanding how higher education transforms society and the world of work. In J. Cote \& S. Pickard (Eds.), Routledge handbook of sociology of higher education (2nd ed.). Routledge.

Fervers, L., Jacob, M., \& Piepenburg, J. (2020). No risk, no gain. Experimental evidence on the role of risk-return preferences for gender differences in higher education - and what to do about it [Unpublished manuscript]. University of Cologne.

Fisser, G. (2019). Wahrnehmung biographischer (Un-)Sicherheit bei „Postdocs“ im Maschinenbau und in der Soziologie [Perception of biographical (in-)security of "Postdocs" in mechanical engineering and sociology]. Gottfried Wilhelm Leibniz University of Hannover. https://doi.org/10.15488/5330

Freitag, W. K. (2012). Zweiter und Dritter Bildungsweg in die Hochschule [Second- and thirdchance educational pathways into universities]. Working Paper No. 253 of the Hans Boeckler Foundation.

Gemeinsame Wissenschaftskonferenz (GWK). (2019). Chancengleichheit in Wissenschaft und Forschung: 23. Fortschreibung des Datenmaterials (2017/2018) zu Frauen in Hochschulen und außerschulischen Forschungseinrichtungen. [Equal opportunities in research and academia: The 23rd update to the data $(2017 / 2018)$ on women at universities and at nonuniversity research organizations]. Materialien der GWK, 65. Bonn, Germany.

Girls’ Day. (n.d.). Girls’Day: Future prospects for girls. https://www.girls-day.de/da ten-fakten/das-ist-der-girls-day/ein-zukunftstag-fuer-maedchen/english

Graf, L. (2013). The hybridization of vocational training and higher education in Austria, Germany, and Switzerland. Budrich UniPress.

Graf, L., \& Powell, J. J. W. (2017). How employer interests and investments shape advanced skill formation. PS: Political Science and Politics, 50(2), 418-422.

Grave, B. S., \& Goerlitz, K. (2012). Wage differentials by field of study - the case of German university graduates. Education Economics, 20(3), 284-302.

Haas, C., \& Hadjar, A. (2019). Students' trajectories through higher education: A review of quantitative research. Higher Education, 79, 1099-1118.

Hägglung, A. E., \& Leuze, K. (2020). Gender differences in STEM expectations across countries: How perceived labor market structures shape adolescents' preferences. Fournal of Youth Studies. https://doi.org/10.1080/13676261.2020.1755029

Han, S. W. (2016). National education systems and gender gaps in STEM occupational expectations. International Journal of Educational Development, 49, 175-187. https:// doi.org/10.1016/j.ijedudev.2016.03.004

Heine, C., Egeln, J., Kerst, C., Müller, E., \& Park, S.-M. (2006). Bestimmungsgründe für die Wahl von ingenieur- und naturwissenschaftlichen Studiengängen. [Determining reasons for 
the study choice of engineering and natural sciences]. HIS Hochschul-InformationsSystem/ZEW Zentrum für Europäische Wirtschaftsforschung (Studien zum deutschen Innovationssystem 4/2006).

Heine, C., Quast, H., Spangenberg, H., Lörz, M., Scheller, P., \& Willich, J. (2017). DZHW panel study of school leavers 2008 -Educational paths of school leavers with a higher education entrance qualification (Version 1.0.0). German Centre for Higher Education Research and Science Studies (DZHW). https://doi.org/10.21249/DZHW:gsl2008:1.0.0

Hetze, P. (2011). Nachhaltige Hochschulstrategien für mehr MINT-Absolventen [Sustainable higher education strategies to increase the number of STEM graduates] (2nd ed.). Stifterverband für die deutsche Wissenschaft.

Heublein, U. (2014). Student drop-out from German higher education institutions. European Fournal of Education, 49(4), 497-513.

Ihsen, S., Jeanrenaud, Y., Wienefoet, V., Hackl-Herrwerth, A., Hantschel, V., \& Hojer, C. (2009). Potenziale nutzen, Ingenieurinnen zurückgewinnen: Drop-Out von Frauen im Ingenieurwesen: Analyse der Ursachen und Strategien zu deren Vermeidung sowie Handlungsempfehlungen für eine erfolgreiche Rückgewinnung. [Using potentials, regaining female engineers: Women's drop out in engineering: Analysis of the causes, strategies as well as recommendations for a successful regain]. Wirtschaftsministerium BadenWürttemberg.

Isphording, I. E., \& Qendrai, P. (2019). Gender differences in student dropout in STEM (Report No. 87). IZA Institute of Labor Economics. http://ftp.iza.org/report_pdfs/ iza_report_87.pdf

Jacob, M., Iannelli, C., Duta, A., \& Smyth, E. (2020). Secondary school subjects and gendered STEM enrollment in higher education in Germany, Ireland, and Scotland. International Fournal of Comparative Sociology, 61(1), 59-78.

Kelly, A. M. (2016). Social cognitive perspective of gender disparities in undergraduate physics. Physical Review Physics Education Research, 12(2), 020116.

Kim, A., \& Kim, K. W. (2003). Returns to tertiary education in Germany and the UK: Effects of fields of study and gender (Paper No. 62). Mannheim Center for European Social Research (MZES). http://edoc.vifapol.de/opus/volltexte/2014/5156/pdf/wp_62.pdf

Komm Mach MINT. (n.d.). "Go MINT"-National Pact for Women in MINT careers. https://www.komm-mach-mint.de/english-information

Kwiek, M., \& Roszka, W. (2020). Gender disparities in international research collaboration: A study of 25,000 university professors. Foumal of Economic Surveys. https:// doi.org/10.1111/joes.12395

Larivière, V., Ni, C., Gingras, Y., Cronin, B., \& Sugimoto, C. R. (2013). Global gender disparities in science. Nature, 504, 211-213.

Leemann, R. J., Dubach, P., \& Boes, S. (2010). The leaky pipeline in the Swiss university system: Identifying gender barriers in postgraduate education and networks using longitudinal data. Swiss Fournal of Sociology, 36(2), 299-323.

Magnusson, C. (2013). More women lower pay? Occupational sex composition, wages and wage growth. Acta Sociologica, 56(3), 227-245.

Makarova, E., Aeschlimann, B., \& Herzog, W. (2019). The gender gap in STEM fields: The impact of the gender stereotype of math and science on secondary students' career aspirations. Frontiers in Education, 4(60), 1-11.

Mann, A., \& DiPrete, T. A. (2013). Trends in gender segregation in the choice of science and engineering majors. Social Science Research, 42(6), 1519-1541.

Meyer, J., \& Strauß, S. (2019). The influence of gender composition in a field of study on students' drop-out of higher education. European Fournal of Education, 54(3), 443-456. 
Moorhouse, E. A. (2017). Sex segregation by field of study and the influence of labor markets: Evidence from 39 countries. International Journal of Comparative Sociology, 58(1), $3-32$.

Nimmesgern, H. (2016). Why are women underrepresented in STEM fields? ChemistryA European Fournal, 22(11), 3529-3530.

Powell, J. J. W., \& Dusdal., J. (2017). The European center of science productivity: Research universities and institutes in France, Germany, and the United Kingdom. In J. J. W. Powell, D. P. Baker, \& F. Fernandez (Eds.), The century of science: The global triumph of the research university (pp. 55-83). Emerald.

Powell, J. J. W., \& Solga, H. (2011). Why are higher education participation rates in Germany so low? Institutional barriers to higher education expansion. Fournal of Education and Work, 24(1-2),49-68.

Reimer, D., \& Steinmetz, S. (2009). Highly educated but in the wrong field? Educational specialisation and labour market risks of men and women in Spain and Germany. European Societies, 11(5), 723-746.

Riegle-Crumb, G., King, B., Grodsky, E., \& Muller, C. (2012). The more things change, the more they stay the same? Prior achievement fails to explain gender inequality in entry into STEM college majors over time. American Educational Research Journal, 49(6), 1048-1073.

Schlenker, E. (2009). The labour supply of female engineers in Germany. Austrian Journal of Statistics, 38(4), 255-263.

Scott, K. A., Aist, G., \& Hood, D. W. (2009). CompuGirls: Designing a culturally relevant technology program. Educational Technology, 49(6), 34-39.

Seymour, E., \& Hewitt, N. M. (1997). Talking about leaving: Why undergraduates leave the sciences. Westview Press.

Seymour, E., \& Hunter, A.-B. (Eds.). (2019). Talking about leaving revisited: Persistence, relocation, and loss in undergraduate STEM education. Springer.

Sikora, J., \& Pokropek, A. (2012). Gender segregation of adolescent science career plans in 50 countries. Science Education, 96(2), 234-264.

Smyth, E., \& Steinmetz, S. (2008). Field of study and gender segregation in European labour markets. International Fournal of Comparative Sociology, 49(4-5),257-281.

Solga, H., \& Pfahl, L. (2009a). Wer mehr Ingenieurinnen will, muss bessere Karrierechancen für Frauen in Technikberufen schaffen [Who wants more female engineers must provide better career opportunities for women in technical occupations]. WZBrief Bildung No. 7.

Solga, H., \& Pfahl, L. (2009b). Doing Gender im technisch-naturwissenschaftlichen Bereich [Doing gender in the technical and natural sciences sector]. In J. Milberg (Ed.), Promotion of young talent in technology and science (pp. 155-218). Springer. https:// bibliothek.wzb.eu/pdf/2009/i09-502.pdf

Statistisches Bundesamt (DESTATIS). (2020a, September 12). Studierende nach Hochschularten, Ländern und Geschlecht [Students by type of higher education institution, country, and gender]. Fachserie 11, Reihe 4.1. https://www.datenportal. bmbf.de/portal/de/K254.html

Statistisches Bundesamt (DESTATIS). (2020b, September 17). Studierende in Mathematik, Informatik, Naturwissenschaft (MINT) und Technik-Fächern [Students in mathematics, informatics, natural sciences (MINT) and technical subjects]. https://www.desta tis.de/DE/Themen/Gesellschaft-Umwelt/Bildung-Forschung-Kultur/Hochschulen/ Tabellen/studierende-mint-faechern.html

Tai, R. H., Liu, C. Q., Maltese, A. V., Fan, X. (2006). Planning early for careers in science. Science, 312(5777), 1143-1144 
United Nations Educational, Scientific and Cultural Organization. (2015). UNESCO science report: Towards 2030. https://unesdoc.unesco.org/ark:/48223/pf0000235406

University of Augsburg. (n.d.). UniMento: Mentoring and career support. https:// www2.uni-augsburg.de/de/projekte/gendermainstreaming/UniMento/download/ information-about-the-project_englisch-version.pdf

Wagner, C. S. (2018). The collaborative era in science. Palgrave Macmillan.

Wahrenburg, M., \& Weldi, M. (2007). Return on investment in higher education: Evidence for different subjects, degrees and gender in Germany (Working Paper No. 709). Goethe University of Frankfurt. https://d-nb.info/1151473529/34

Wissenschaftsrat. (2013). Perspektiven des deutschen Wissenschaftssystems. [Perspectives of the German science system]. (Drs. 3228-3213). Braunschweig.

Wolffram, A., Derboven, W., \& Winker, G. (2009). Women withdrawers in engineering studies: Identity formation and learning culture as gendered barriers for persistence? Equal Opportunities International, 28(1), 36-49.

Xie, Y., \& Shauman, K. A. (2003). Women in science - Career opportunities and outcomes. Harvard University Press.

Xie, Y., Fang, M., \& Shauman, K. A. (2015). STEM education. Annual Review of Sociology, 41(1), 331-357.

Zippel, K. (2017). Women in global science. Advancing academic careers through international collaboration. Stanford University Press. 